\title{
Microtensile Bond Strength of Adhesive Systems to Dentin with or without Application of an Intermediate Flowable Resin Layer
}

\author{
Mario Fernando DE GOES ${ }^{1}$ \\ Marcelo GIANNINI ${ }^{1}$ \\ Vinícius DI HIPÓLITO ${ }^{1}$ \\ Marcela Rocha de Oliveira CARRILHO ${ }^{1}$ \\ Márcia DARONCH${ }^{2}$ \\ Frederick Allen RUEGGEBERG ${ }^{2}$ \\ ${ }^{1}$ Department of Restorative Dentistry, School of Dentistry of Piracicaba, \\ State University of Campinas, Piracicaba, SP, Brazil \\ ${ }^{2}$ Department of Oral Rehabilitation, School of Dentistry, Medical College of Georgia, Augusta, GA, USA
}

\begin{abstract}
This study evaluated the effect of flowable composite resin application on the microtensile bond strength ( $\mu$ TBS) of adhesive systems to dentin. Occlusal surfaces of human third molars were ground to obtain flat dentin surfaces. The crown of each tooth was sectioned occluso-gingivally into four quarters with a water-cooled diamond saw. One of the following adhesive systems was applied to dentin surface in each quarter of the same tooth, following manufacturers' instructions: Scotchbond Multipurpose, Single Bond Adper Prompt and Clearfil SE Bond. Experimental and control groups received the same treatment, except for the fact that a layer of flowable composite (Filtek Flow) was placed and light-cured on top of the adhesive layer in the specimens of the experimental groups. Resin composite (Filtek Z250) crown buildups were then made on the bonded surfaces and incrementally light-cured for $20 \mathrm{~s}$. The restored teeth were stored in water at $37^{\circ} \mathrm{C}$ for $24 \mathrm{~h}$. Each tooth quarter was serially cut in a longitudinal direction in order to obtain several bonded sticks $\left(0.9-\mathrm{mm}^{2}\right.$ in cross-section). Maximal microtensile stress (in $\mathrm{MPa}$ ) at failure was recorded using a universal testing machine. Data were analyzed by two-way ANOVA and Tukey's test at 5\% significance level. Placement of a low-viscosity resin to the hybridized dentin increased the $\mu$ TBS for all tested adhesive systems. However, such increase was significant only for Clearfil SE Bond $(\mathrm{p}<0.05)$. When the restorations were placed without low-viscosity resin, Clearfil SE Bond presented higher $\mu$ TBS than Adper Prompt $(\mathrm{p}<0.05)$. For the groups treated with flowable composite, Clearfil SE Bond produced the highest $\mu$ TBS means to dentin. In conclusion, the effect of the addition of an intermediate flowable composite layer on $\mu$ TBS to dentin was material-dependent and resulted in an increased adhesion for all tested materials, though with significance only for Clearfil SE Bond.
\end{abstract}

Key Words: dentin, adhesive system, bond strength, composite resin.

\section{INTRODUCTION}

Contemporary dental adhesive systems can be classified according to application techniques as etchand-rinse or self-etching adhesive systems. Different approaches involving the number of steps and levels of sensitivity have been used to bond resin-based materials to enamel and dentin. However, in order to simplify the bonding protocol, reducing number of bottles and clinical steps, manufacturers have attempted to produce all-in-one systems or combine together either primer and bonding resin or etchant and primer agent (1-3).

Conventional adhesive systems involve a separate etch-and-rinse step, followed by priming and resin adhesive application. Simplified two-step etch-and-rinse systems combine the primer and adhesive resin into one application (1). Self-etching primer adhesives are applied without separate acid etching, rinsing and moist-

Correspondence: Prof. Dr. Marcelo Giannini, Departamento de Odontologia Restauradora, Faculdade de Odontologia de Piracicaba, UNICAMP, Av. Limeira, 901, 13414-903 Piracicaba, SP, Brasil. Tel: +55-19-2106-5338. Fax: +55-19-2106-5218. e-mail: giannini@fop.unicamp.br 
ening control steps because acidic monomers are included in the primer solution (2). Self-etching "all-inone" adhesives consist of a complex solution of an acidic-monomer and must etch, prime and bond in a single application procedure (3). These one-step selfetching systems present a shorter clinical application time, reduction in technique sensitivity and are considered user-friendly.

The use of a bonding systems associated to a low-viscosity resin has been indicated to improve the bond strength, marginal sealing and interfacial adaptation of restorative composites to dentin (4-7). Studies have suggested that the application of a low-viscosity resin can preserve and protect the hybrid layer during the shrinkage of restorative composites or resin cements, minimizing postoperative sensitivity and increasing restoration longevity (8-10). Therefore, the purpose of this study was to evaluate the effect of flowable composite resin application on the $\mu \mathrm{TBS}$ of adhesive systems to dentin. The null hypothesis is that bond strength is not influenced by the application of a low-viscosity resin over the bonded dentin regardless of the type of adhesive system used.

\section{MATERIAL AND METHODS}

Twelve extracted, caries-free human third molars were used in this study, according to protocols approved by Ethics in Research Committee of the School of Dentistry of Piracicaba, State University of Campinas (37/2003), Brazil. The teeth were decoronated with a water-cooled diamond saw (Isomet; Buehler Ltd., Lake Bluff, IL, USA) and the crown of each tooth was sectioned in an occlusogingival direction (mesiodistally and buccolingually) into four quarters. The exposed middle dentin surfaces were wet-polished with 600-grit $\mathrm{SiC}$ paper to create a standardized smear layer before adhesive system application.

The adhesive systems used in this study were: Scotchbond Multipurpose (3M/ESPE, St. Paul, MN, USA), Single Bond (3M/ESPE), Adper Prompt (3M/ ESPE) and Clearfil SE Bond (Kuraray Medical Inc., Kurashiki, Japan) (Table 1). The restorative resin composites were Filtek Flow (3M/ESPE) and Filtek Z250 (3M/ESPE). The dentin segments were randomly assigned to 8 groups $(n=6)$, according to the adhesive system and application of an intermediate flowable composite layer between the adhesive and the resin.
After bonding procedures following the manufacturers' directions, half of groups received a thin (0.5-mm-thick) layer of flowable composite on top of the adhesive layer. Three layers of Z250 were applied to specimens to build up a crown of approximately $6.0 \mathrm{~mm}$ in height. Each layer was light cured for $40 \mathrm{~s}$ with a halogen light-curing unit (XL 3000, 3M/ESPE). The bonded teeth were then stored in water at $37^{\circ} \mathrm{C}$ for 24 $\mathrm{h}$ and then serially sectioned in a longitudinal direction into 0.7-mm-thick slabs with a diamond saw. Each slab was further sectioned to produce two bonded specimens or sticks of approximately $0.9 \mathrm{~mm}^{2}$. Each bonded

Table 1. Composition and application steps of the adhesive systems.

\begin{tabular}{|c|c|c|}
\hline Material & Composition & Steps \\
\hline $\begin{array}{l}\text { ScotchBond } \\
\text { Multi-Purpose } \\
\text { (etch-and-rinse) } \\
\text { (3 steps) }\end{array}$ & $\begin{array}{c}\text { etchant: } 35 \% \text { phosphoric } \\
\text { acid; primer: HEMA, PAA } \\
\text { and water; adhesive: } \\
\text { Bis-GMA and HEMA }\end{array}$ & $\begin{array}{l}\mathrm{a}, \mathrm{b}, \mathrm{c} \\
\mathrm{e} 1, \mathrm{f}, \mathrm{g}\end{array}$ \\
\hline $\begin{array}{l}\text { Single Bond } \\
\text { (etch-and-rinse) } \\
\quad(2 \text { steps })\end{array}$ & $\begin{array}{c}\text { conditioner: } 35 \% \text { phosphoric } \\
\text { acid; adhesive: Bis-GMA, } \\
\text { HEMA, PAA, dimethacrylates, } \\
\text { ethanol and water }\end{array}$ & $\begin{array}{c}\mathrm{a}, \mathrm{b}, \mathrm{c} \\
\mathrm{f}, \mathrm{g}\end{array}$ \\
\hline $\begin{array}{l}\text { Adper Prompt } \\
\text { (self-etching) } \\
\quad(1 \text { step })\end{array}$ & $\begin{array}{c}\text { Liquid } 1 \text { (red blister): } \\
\text { methacrylated phosphoric } \\
\text { esters, Bis-GMA, CQ, } \\
\text { stabilizers; } \\
\text { Liquid } 2 \text { (yellow blister): } \\
\text { water, HEMA, polyalkenoic } \\
\text { acid, copolymer, stabilizers }\end{array}$ & $\mathrm{c}, \mathrm{d}, \mathrm{e} 2, \mathrm{~g}$ \\
\hline $\begin{array}{l}\text { Clearfil SE Bond } \\
\text { (self-priming) } \\
\quad(2 \text { steps })\end{array}$ & $\begin{array}{l}\text { acidic primer: MDP, } \\
\text { HEMA, hydrophilic } \\
\text { dimethacrylate, N,N-diethanol } \\
\text { p-toluidine and water; } \\
\text { adhesive: } \text { MDP, Bis-GMA, } \\
\text { HEMA, hydrophobic } \\
\text { dimethacrylate, CQ, } \\
\text { N,N-diethanol p-toluidine and } \\
\text { silanated colloidal silica }\end{array}$ & $\mathrm{c}, \mathrm{e} 2, \mathrm{f}, \mathrm{g}$ \\
\hline
\end{tabular}

MDP= 10-10-methacryloyloxydecyl dihydrogen phosphate; $\mathrm{CQ}=$ camphorquinone; HEMA= 2-hydroxyethyl methacrylate; Bis-GMA = bisphenol-glycidil dimethacrylate; PAA= polyalkenoic acid copolymer. Steps: a: acid etching; b: rinsing; c: gentle air-drying; d: adhesive mixing; e: 1- primer application/2acidic primer application; f: adhesive application; g: light curing. 
stick was fixed to the grips of a micro-tensile device with cyanoacrylate adhesive (Zapit, DVA, Corona, CA, USA) and tested in $\mu$ TBS in a testing machine (4411, Instron Co., Canton, MA, USA) at $0.5 \mathrm{~mm} / \mathrm{min}$ until failure. After testing, specimens were removed from the fixtures with a scalpel blade and the cross-sectional area at the site of fracture was measured to the nearest 0.01 $\mathrm{mm}$ with a digital caliper (Starret 727-6/150, Starret, SP, Brazil).

$\mu$ TBS means for each group were calculated from the mean of each restored dentin specimen. Data were analyzed by two-way ANOVA (adhesive system $x$ flowable resin application) and Tukey's test. Statistical significance was set at 5\%. The dentin and composite sides of failed specimens were sputter-coated with gold (SCD 050; Balzers, Schaan, Leichtenstein) and observed with a scanning electron microscope (JSM $5600 \mathrm{LV}$; JEOL, Tokyo, Japan). SEM micrographs of representative areas of the surface were taken at $\times 85$ and $\times 350$ magnification.

\section{RESULTS}

Table 2 shows the $\mu$ TBS means $( \pm \mathrm{SD})$ for the adhesive systems coated or not with an intermediate layer of flowable resin. Two-way ANOVA showed statistically significant differences for both factors (adhesive system and flowable resin) $(\mathrm{p}<0.0001)$ and significant interaction between them $(\mathrm{p}=0.008)$.

The application of a low-viscosity resin to the hybridized dentin increased the $\mu$ TBS for all tested adhesive systems. However, such increase was significant only for Clearfil SE Bond $(\mathrm{p}<0.05)$. When the restorations were placed without low-viscosity resin, Clearfil SE Bond self-etching primer presented higher $\mu$ TBS than Adper Prompt self-etching adhesive $(\mathrm{p}<0.05)$. For the groups coated with the flowable resin, Clearfil SE Bond produced the highest $\mu$ TBS to dentin.

The fracture between adhesive layer and composite was the most predominant failure pattern for the groups restored without flowable resin, although cohe-

Table 2. $\mu$ TBS means $( \pm \mathrm{SD})$ in MPa for the experimental groups.

\begin{tabular}{lcccc}
\hline & $\begin{array}{c}\text { Scotchbond } \\
\text { Multi-Purpose }\end{array}$ & $\begin{array}{c}\text { Single } \\
\text { Bond }\end{array}$ & $\begin{array}{c}\text { Adper } \\
\text { Prompt }\end{array}$ & $\begin{array}{c}\text { Clearfil } \\
\text { SE Bond }\end{array}$ \\
\hline $\begin{array}{lcccc}\text { No flowable } \\
\text { composite }\end{array}$ & $25.71 \pm$ & $29.27 \pm$ & $19.35 \pm$ & $32.85 \pm$ \\
& $7.07 \mathrm{Aab}$ & $8.57 \mathrm{Aab}$ & $6.05 \mathrm{Aa}$ & $9.3 \mathrm{Ab}$ \\
$\begin{array}{l}\text { With flowable } \\
\text { composite }\end{array}$ & $30.77 \pm$ & $32.25 \pm$ & $28.09 \pm$ & $54.07 \pm$ \\
& $12.02 \mathrm{Aa}$ & $13.51 \mathrm{Aa}$ & $10.39 \mathrm{Aa}$ & $15.55 \mathrm{Bb}$
\end{tabular}

Means followed by different letters indicate statistically significant difference at $5 \%$ (uppercase letters in columns and lowercase letters in rows).
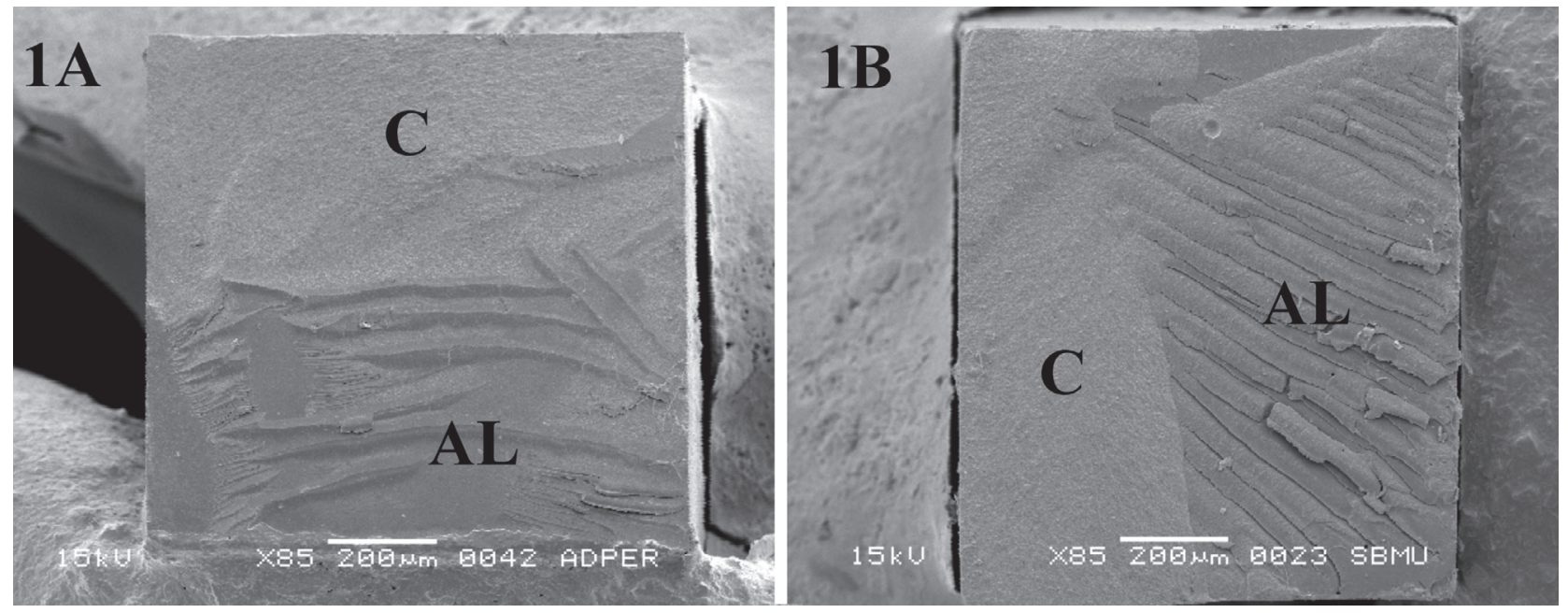

Figure 1. SEM photomicrographs illustrating fractured surfaces of groups without flowable composite (1A- Adper Prompt and 1BScotchbond Multipurpose). The failures occurred within the adhesive layer or composite; and between the adhesive and composite (Ccomposite; AL- adhesive layer). 
sive fractures in hybrid layer, dentin or composite were also observed in few specimens (Figs. 1A and 1B). For Adper Prompt, the application of a flowable resin layer did not affect the failure pattern. For the other materials, flowable resin application produced partial or total cohesive failure in the low-viscosity resin layer and within the adhesive system layer or hybrid layer (Figs. $2 \mathrm{~A}$ and $2 \mathrm{~B}$ ).

\section{DISCUSSION}

Flowable resin composites are relatively hydrophobic materials and their use as liner in composite restorations has been extensively suggested $(4-6,9)$. These materials comprise the same particle size of restorative composites and most of them are classified as minifilled or microhybrid. However, the decrease of the filler content and the increase of the resin matrix make them less viscous than restorative composites, and thus these materials are also known as low-viscosity resin composites. According to Behle (8) and Bayne et al. (11), one important property of a flowable resin composite is related to its elastic modulus, which is significantly lower than that of traditional hybrid composites (30 to $50 \%$ ). In addition, Labella et al. (12) showed that the elastic moduli of flowable composites were in the low-medium range, hybrid composites had the highest values and microfilled the lowest ones.
The effects of mechanical stress during restorative composite or resin cement polymerization on the bonding of adhesive systems to the prepared tooth walls is one of the main causes of marginal failure $(7,10,13)$. An advantage associated with a lower elastic modulus of a low-viscosity resin is its ability to absorb parts of the polymerization shrinkage of restorative composite resins, preserving the hybrid layer and avoiding marginal gap formation. As the combination of low shrinkage and low rigidity result in less damage to the interface (12), the flowable materials could be important during restorative composite polymerization shrinkage, mainly in three-dimensional tooth preparations, according to cavity configuration factor $(8,11)$. Conversely, some studies have shown higher shrinkage for flowable composites $(12,14)$, indicating a potential for higher interfacial stresses with the same behavior of hybrid restorative composite resins (14).

In the present study, flat dentin surfaces were used as bonding substrates, which are not subjected to the same polymerization contraction stresses faced on three-dimensional tooth preparations (15). Although all adhesives showed a numerical increase of $\mu$ TBS when using a low-viscosity resin layer, only Clearfil SE Bond values were significantly increased. As the application of the flowable resin did not affect $\mu$ TBS means for any of the tested adhesive systems, it was assumed that the study hypothesis should be only partially accepted.
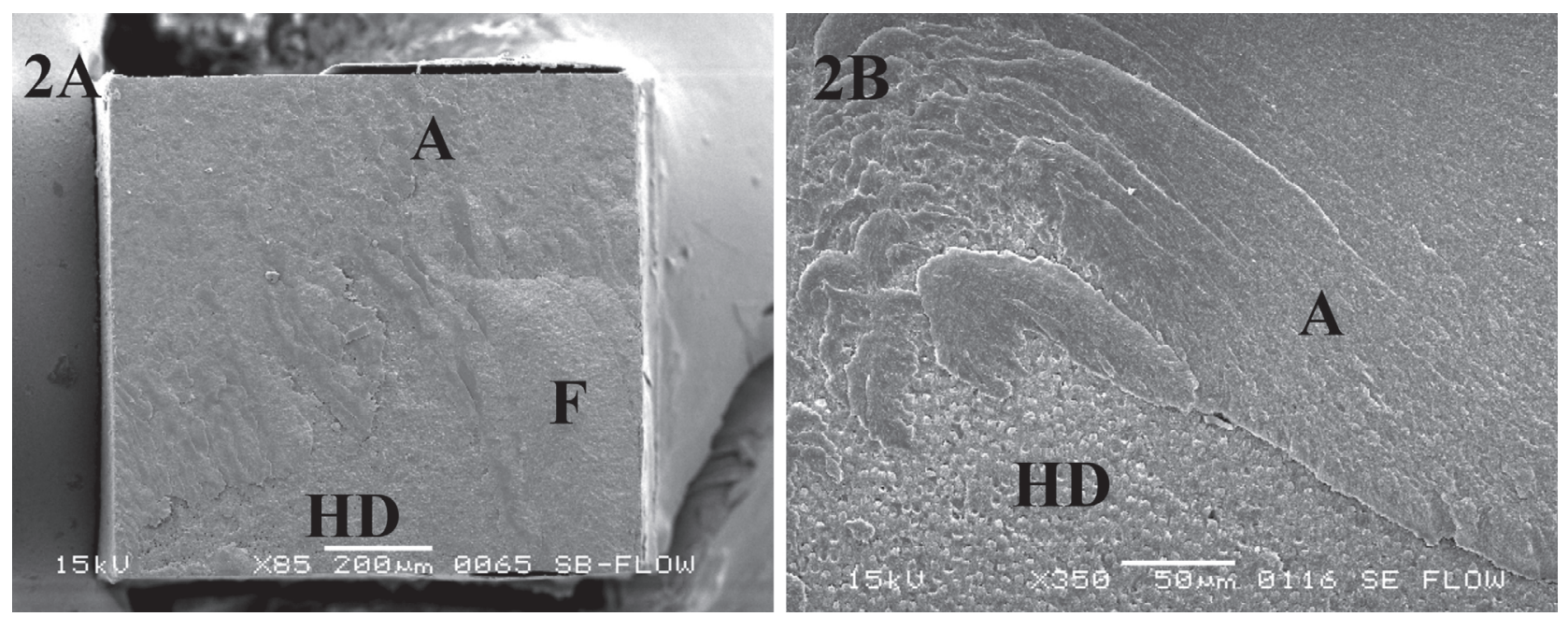

Figure 2. SEM photomicrographs illustrating fractured surfaces of groups with flowable application (2A-Single Bond and 2B- Clearfil SE Bond). The failures occurred within the adhesive resin or hybrid layer; and within the flowable composite (HD- hybridized dentin; A- adhesive resin; F- flowable composite). 
Studies that tested Clearfil SE Bond, Single Bond and Scotchbond MP adhesive systems without a lowviscosity composite liner showed similar bond strength among them $(1,16,17)$, in spite of the different approaches of hybridization (2). Adper Prompt is considered as an all-in-one self-etching adhesive and, despite its simpler clinical application, this type of material does not provide the formation of a high-quality hybrid layer compared to self-etching primers and conventional etch-and-rinse adhesives. All-in-one adhesives are a complex mixture of hydrophobic acidic monomer, hydrophilic resins, solvent and water. The lack of hydrophobic resins for hybrid layer formation can compromise bond strength to dentin (3) and influence the failure mode, as observed in this current study.

In addition to protection to the hybrid layer, the application of an additional low-viscosity resin layer can improve the degree of conversion of the underlying adhesive resin, increasing the bond strength (10). Partially cured monomer surface can be formed on top of the adhesive layer after light irradiation due to atmospheric oxygen inhibition, compromising the bonding between adhesive and composite (18). Moreover, studies have shown that an uncured layer from acidic adhesive solutions could adversely interact with dualcured resins or with light-cured restorative composites, also affecting the bond strength $(19,20)$. A low-viscosity or a hydrophobic resin layer application could overcome these adverse reactions. A resin coating technique has been suggested, in which both hybrid layer and tight sealing film are formed on dentin surface with a bonding agent and a low viscosity microfilled resin applied to the hybridized dentin. This restorative technique enables coverage and protection of the prepared dentin immediately after cavity preparation, improving the interfacial integrity and providing high bond strength of restorative composites $(7,10)$.

The polymerization of Clearfil SE Bond depends on water evaporation after priming, buffering of acidic primer and a proper mixture between primer and bonding resin. The additional application of a hydrophobic flowable resin may have improved the polymerization of the adhesive resin mixture, which resulted in higher bond strength and changed the fractured areas involved in failure mode (Fig. 2). The analyses of failure modes showed that the use of low-viscosity resin liner may improve the marginal seal of the dentin tubules, since a large number of partial or total failures within the flowable composite layer and partially within the adhesive resin were observed. SEM analysis of fractured specimens performed by Montes et al. (5) and Reis et al. (6) revealed the same failure mode when the lowviscosity microhybrid resin composite was either used or not. Restorations without flowable resin fractured close to the problematic and weaker interfaces that were composed of adhesive layer and restorative composite (Fig. 1), showing the importance of the application of an additional low-viscosity resin layer to protect and improve the quality of hybrid layer.

According to the methodology employed and based on the obtained results, it may be concluded that the effect of a low-viscosity, flowable resin layer application on $\mu$ TBS to dentin was material-dependent, and increased the adhesion of all materials, but only Clearfil SE Bond was significantly increased.

\section{RESUMO}

Este estudo avaliou o efeito da aplicação de uma resina flow na resistência de união (RU) (microtração) de sistemas adesivos à dentina. Superfícies oclusais de terceiros molares humanos foram abrasionadas para formar superfícies dentinárias planificadas. As coroas foram seccionadas no sentido oclusogengival em quatro partes de tamanhos similares com disco diamantado sob refrigeração. Os sistemas adesivos (Scotchbond Multipurpose; Single Bond; Adper Prompt e Clearfil SE Bond) foram aplicados nas superfícies dentinárias, de acordo com as instruções dos fabricantes, sendo cada um deles em uma das quatro partes de um mesmo dente. Os grupos experimentais e controle receberam o mesmo tratamento, porém a resina flow (Filtek Flow) foi aplicada e fotoativada sobre os sistemas adesivos nos espécimes dos grupos experimentais. Um bloco de compósito (Filtek Z250) foi confeccionado em incrementos sobre as superfícies tratadas com o sistema adesivo e fotoativado por $20 \mathrm{~s}$. Os dentes restaurados foram armazenados em água a $37^{\circ} \mathrm{C}$ por $24 \mathrm{~h} \mathrm{e}$ seccionados longitudinalmente para obtenção de espécimes com formato de paralelepípedo, com $0,9 \mathrm{~mm}^{2}$ na área de união. $\mathrm{O}$ ensaio de tração foi realizado em máquina universal de ensaios e os valores de RU foram expressos em MPa. Os dados foram analisados pela ANOVA (dois fatores) e teste de Tukey (5\%). A aplicação da resina flow na dentina previamente hibridizada aumentou a RU para todos os sistemas adesivos, entretanto, foi estatisticamente significativa somente para o adesivo Clearfil SE Bond ( $p<0,05)$. Quando as restaurações foram confeccionadas sem a resina de baixa viscosidade, o Clearfil SE Bond obteve maior valor de RU que o adesivo Adper Prompt $(p<0,05)$. Para os grupos com a resina flow, o Clearfil $\mathrm{SE}$ Bond resultou no maior valor médio de RU à dentina. Conclui-se que o efeito da aplicação da resina flow foi depende do sistema adesivo utilizado e indicou um aumento na RU para todos os sistemas adesivos testados, entretanto, somente para o adesivo Clearfil SE Bond o aumento foi significativo. 


\section{ACKNOWLEDGEMENTS}

This study was supported by grants from FAPESP (03/080907); $\mathrm{CNPq}(310845 / 2006-8)$ and CAPES/PRODOC (Dr. Carrilho).

\section{REFERENCES}

1. Breschi L, Mazzoni A, Ruggeri A, Cadenaro M, Di Lenarda R, De Stefano Dorigo E. Dental adhesion review: aging and stability of the bonded interface. Dent Mater 2008;24:90101

2. Tay FR, Sano H, Carvalho RM, Pashley DH. An ultrastructural study of the influence of acidity of self-etching primers and smear layer thickness on bonding to intact dentin. J Adhes Dent 2000;2:83-98.

3. Carvalho RM, Tay FR, Giannini M, Pashley DH. Effects of pre- and post-bonding hydration on bond strength to dentin. J Adhes Dent 2004;6:13-17.

4. Beznos C. Microleakage at the cervical margins of composite class II cavities with different restoratives techniques. Oper Dent 2001;26:60-69.

5. Montes MAJR, De Goes MF, Cunha MRB, Soares AB. A morphological and tensile bond strength evaluation of an unfilled adhesive with low-viscosity composites and a filled adhesive in one and two coats. J Dent 2001;29:435-441.

6. Reis AF, Giannini M, Ambrosano GM, Chan DCN. The effects of filling techniques and a low-viscosity composite liner on bond strength to class II cavities. J Dent 2003;31:59-66.

7. Jayasooriya PR, Pereira PNR, Nikaido T, Burrow MF, Tagami $\mathrm{J}$. The effect of a resin coating on the interfacial adaptation of composite inlays. Oper Dent 2003;28:28-35.

8. Behle C. Flowable composites: properties and applications. Pract Period Aesthetic Dent 1998;10:347-351.

9. Leevailoj C, Cochran MA, Matis BA, Moore BK, Platt JA. Microleakage of posterior packable composites with and without flowable liners. Oper Dent 2001;26:302-307.

10. Jayasooriya PR, Pereira PNR, Nikaido T, Tagami J. Efficacy of a resin coating on bond strengths of resin cement to dentin. J Esthet Rest Dent 2003;15:105-113.
11. Bayne SC, Thompson JY, Swift Jr EJ, Stamadiades P, Wilkerson JA. A characterization of first-generation flowable composites. J Am Dent Assoc 1998;129:567-577.

12. Labella R, Lambrechts P, Van Meerbeek B, Vanherle G Polymerization shrinkage and elasticity of flowable composites and filled adhesives. Dent Mater 1999;15:128-137.

13. Calheiros FC, Sadek FT, Boaro LC, Braga RR. Polymerization stress related to radiant exposure and its effect on microleakage of composite restorations. J Dent 2007;35:946952.

14. Braga RR, Hilton TJ, Ferracane JL. Contraction stress of flowable composite materials and their efficacy as stressrelieving layers. J Am Dent Assoc. 2003;134:721-728.

15. Braga RR, Boaro LC, Kuroe T, Azevedo CL, Singer JM. Influence of cavity dimensions and their derivatives (volume and ' $\mathrm{C}$ ' factor) on shrinkage stress development and microleakage of composite restorations. Dent Mater 2006;22:818-823.

16. Toledano M, Osório R, Ceballos L, Fuentes MV, Fernandes CA, Tay FR, Carvalho RM. Microtensile bond strength of several adhesive systems to different dentin depths. Am J Dent 2003;16:292-298.

17. Giannini M, Martins LRM, Dias CTS. Comparison of bond strength between conventional three-step and one bottle dentin adhesives. Rev ABO Nac 2003;11:23-27.

18. Endo T, Finger WJ, Hoffmann M, Kanehira M, Komatsu M. The role of oxygen inhibition of a self-etch adhesive on selfcure resin composite bonding. Am J Dent 2007;20:157-160.

19. Tay FR, King NM, Suh BI, Pashley DH. Effect of delayed activation of light-cured resin composites on bonding of Allin-one adhesives. J Adhes Dent 2001;3:207-225.

20. Giannini M, De Goes MF, Nikaido T, Shimada Y, Tagami J. Influence of activation mode of dual-cured resin composite cores and low-viscosity composite liner on bond strength to dentin treated with self-etching adhesives. J Adhes Dent 2004;6:301-306.

Accepted December 22, 2007 